\title{
The role of imaging in congenital adrenal hyperplasia
}

\author{
O papel dos métodos de imagem em hiperplasia congênita \\ de suprarrenal
}

Sara Reis Teixeira', Paula Condé Lamparelli Elias², Marco Túlio

Soares Andrade ${ }^{1}$, Andrea Farias Melo', Jorge Elias Junior ${ }^{1}$

\begin{abstract}
Congenital adrenal hyperplasia $(\mathrm{CAH})$ is an autossomic recessive disorder caused by impaired steroidogenesis. Patients with $\mathrm{CAH}$ may present adrenal insufficiency with or without salt-wasting, as well as various degrees of virilization and fertility impairment, carrying a high incidence of testicular adrenal rest tumors and increased incidence of adrenal tumors. The diagnosis of $\mathrm{CAH}$ is made based on the adrenocortical profile hormonal evaluation and genotyping, in selected cases. Follow-up is mainly based on hormonal and clinical evaluation. Utility of imaging in this clinical setting may be helpful for the diagnosis, management, and follow-up of the patients, although recommendations according to most guidelines are weak when present. Thus, the authors aimed to conduct a narrative synthesis of how imaging can help in the management of patients with $\mathrm{CAH}$, especially focused on genitography, ultrasonography, computed tomography, and magnetic resonance imaging. Arq Bras Endocrinol Metab. 2014;58(7):701-8
\end{abstract}

Keywords

Adrenal hyperplasia, congenital; magnetic resonance imaging; computed tomography; ultrasonography; diagnostic imaging

\section{RESUMO}

Hiperplasia congênita de suprarrenal (CAH) é uma doença autossômica recessiva causada por deficiências enzimáticas na esteroidogênese. Clinicamente, os pacientes com CAH podem apresentar insuficiência adrenal com ou sem perda de sal, vários graus de virilização e diminuição na fertilidade, alta incidência de restos adrenais testiculares e de tumores adrenais. $\mathrm{O}$ diagnóstico de $\mathrm{CAH}$ é feito baseado nos resultados da avaliação hormonal e genotípica, em casos selecionados. $\mathrm{O}$ seguimento dos pacientes é principalmente feito com avaliação clínica e hormonal. Métodos de diagnóstico por imagem podem ser muito úteis não só no diagnóstico como no manejo e seguimento dos pacientes com $\mathrm{CAH}$. Porém, as recomendações, de acordo com a maioria dos consensos, quando existem, são escassas. Nesse contexto, com base em uma revisão sistemática, o objetivo deste artigo foi sintetizar a literatura em relação a como os métodos de diagnóstico por imagem podem ser úteis no manejo dos pacientes com $\mathrm{CAH}$, com foco em genitografia, ultrassonografia, tomografia computadorizada e ressonância magnética. Arq Bras Endocrinol Metab. 2014;58(7):701-8

\section{Descritores}

Hiperplasia adrenal congênita; ressonância magnética; tomografia computadorizada; ultrassonografia; diagnóstico por imagem
1 Department of Internal Medicine, Division of Radiology, Clinical Hospital, Ribeirao Preto Medical School, University of Sao Paulo (FMRP-USP), Ribeirao Preto, SP, Brazil ${ }^{2}$ Department of Internal Medicine, Division of Endocrinology, Clinical Hospital, FMRP-USP, Ribeirao Preto, SP, Brazil

\author{
Correspondence to: \\ Jorge Elias Junior \\ Radiology Division, \\ Ribeirao Preto Medical School \\ University of Sao Paulo \\ Av. Bandeirantes, 3900 \\ 14049-090 - Ribeirao Preto, SP, Brazil \\ jejunior@fmrp.usp.br
}

Received on Mar/21/2014 Accepted on Jun/17/2014

DOI: 10.1590/0004-2730000003371

\section{INTRODUCTION}

$\mathrm{C}$ ongenital adrenal hyperplasia (CAH) is an autossomic recessive disorder caused by impaired steroidogenesis, in approximately $95 \%$ of the cases, secondary to 21-hydroxylase deficiency. Patients may present adrenal insufficiency with or without salt-wasting, as well as various degrees of virilization and fertility im- pairment, carrying a high incidence of testicular adrenal rest tumors (TART) and increased incidence of adrenal tumors (1). Neonatal screening is recommended because it reduces and prevents morbidity and mortality from salt-losing crisis (2). The diagnosis is made with adrenocortical profile hormonal evaluation and genotyping in selected cases (2). 
Utility of imaging in this clinical setting may be helpful for the diagnosis, management, and follow-up of the patients, although recommendations according to most guidelines are weak when present (2). Bone mineral density evaluation in children is not recommended and adrenal imaging is suggested only for patients with an atypical course (2). Conversely, CAH must be excluded in cases of adrenal incidentaloma supposedly asymptomatic or oligosymptomatic. To evaluate gonads, ultrasonography (US) is recommended for screening males from adolescence, but there is no recommendation to screen females (2).

Thus, the authors aim to conduct a narrative synthesis of how imaging can help in the management of patients with $\mathrm{CAH}$, especially focused on genitography (GX), US, computed tomography (CT), and magnetic resonance imaging (MRI).

\section{SEARCH STRATEGY AND SELECTION OF ARTICLES}

A systematic search was conducted in MedLine ${ }^{\circledR}$ (from 1950 to July 2013) and in Web of Science ${ }^{\circledR}$ (from 1965 to July 2013) databases for articles published in English, Spanish, Portuguese, and French. On MedLine ${ }^{\circledR}$, the MeSH term "adrenal hyperplasia, congenital" was searched with the other imaging related MeSH terms with AND at a time using "ultrasonography", or "magnetic resonance imaging", or "diffusion magnetic resonance imaging", or "tomography, X-ray computed", or "multidetector computed tomography", or "positron-emission tomography and computed tomography", or "tomography scanners, X-ray computed radiography", or "diagnostic imaging". Web of Science ${ }^{\circledR}$ was searched for articles with the search terms "congenit* and adren* and hyperpl*" "AND imag*". Books and other selected references cited in the most relevant retrieved articles were also reviewed.

Studies that were conducted in animals and in which only scintigraphy or nuclear imaging modalities were used as imaging modalities were not within the scope of this review. Also, studies that only used X-ray to evaluate bone age or any imaging modalities to assess bone mineral density were not extensively reviewed, as it is well established by the guidelines that bone age should be assessed annually after 2 years of age and regular evaluation of bone mineral density is not recommended (2).

\section{Imaging}

\section{Genitography}

The urogenital sinus is the embryologic precursor of the bladder, urethra, and distal third of the vagina in females. Excessive androgen exposure in utero leads to virilization of the external genitalia and urogenital malformations in females with CAH (1). Signs of urogenital sinus malformation secondary to virilization are hydrocolpos or hydrometrocolpos and only two apertures (one of them is the anus) in the perineal region associated with ambiguous genitalia (3). Typically, female patients with classic $\mathrm{CAH}$ have ambiguous genitalia at birth. Thus an anatomic detailed image plays an important role in planning strategy for feminizing surgery. Genitography shows the urethra, the level of external sphincter, the presence or absence of the vagina, the urethrovaginal confluence, and the cervical impression of the uterus (3) (Figure 1).

Genitography associated with voiding cistography has also the ability to show upper genitourinary abnormalities, present in $21 \%-80 \%$ (4) of the patients with $\mathrm{CAH}$, mostly seen in girls.

Although some authors concluded that genitography did not add information to endoscopic (5) or surgical findings, many advocate its use as part of routine investigation in female patients with CAH (4), particularly in those infants with ambiguous genitalia.

\section{Ultrasonography}

US is the modality of choice to image abdominal and pelvic organs in children and fetuses. It is widely available, versatile, and portable, with lack of ionizing radiation, there is no need for sedation, and provides highresolution images in any required plane.

The adrenal glands in young children and fetuses are well depicted with US, especially in the neonate period. Sonographic abnormalities of the adrenal glands in $\mathrm{CAH}$ are similar in pre- and postnatal periods. The most prevalent sign is bilateral enlarged glands with width measurements of one limb $\geq 4 \mathrm{~mm}$ (6). In addition, adrenal size was positively correlated with plasma concentration of dehydroepiandrosterone sulphate (7). Also, a coiled or cerebriform pattern $(8,9)$ is specific for this condition (Figure 1A). This finding should prompt a thorough investigation in male fetus and whenever a corticoid therapy is initiated serial US will show decrease in size of the adrenal glands (10). In infants, the morphology was shown to be of valuable importance while waiting for laboratory results in patients investigated for suspicious of the disease, enabling earlier diagnosis and treatment (9). However, it is very important to notice that normal adrenal glands do not exclude the possibility of $\mathrm{CAH}(6)$. 


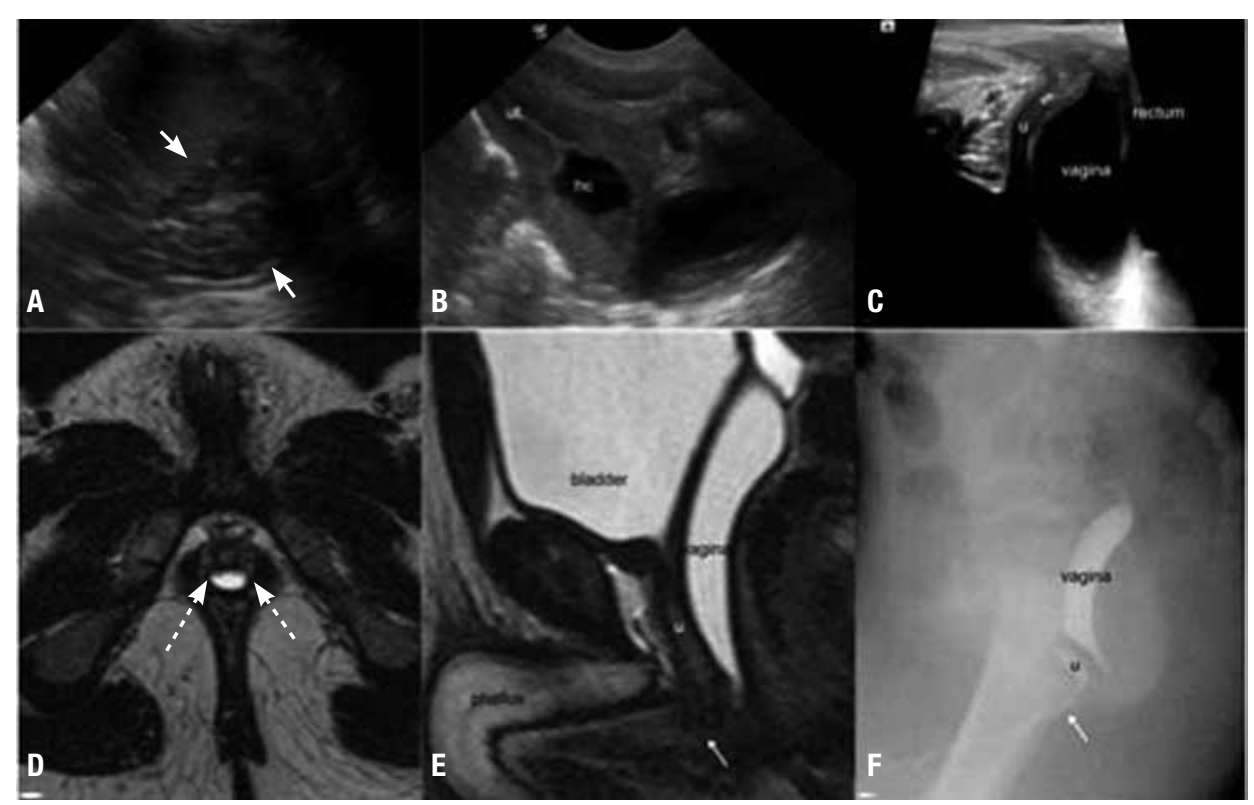

Figure 1. Newborn with "non palpable testicles". Ultrasonography $(\mathbf{A}-\mathbf{C})$ showed enlarged and cerebriform pattern of the adrenal glands (arrows in A). Sagittal view of the pelvis through the abdominal wall (B): the uterus ("ut") and the presence of hydrocolpus ("hc") are well depicted. The ovaries (not shown) were also present. Sagittal ultrasonography view of the pelvis through the perineum (C) was not sufficient to show with high confidence the confluence of the urethra and the vagina, which was better viewed on magnetic resonance imaging (MRI) (E, sagittal T2-weighetd MRI of the pelvis) and genitography $(\mathbf{F})$. The arrows in $(\mathbf{E})$ and $(\mathbf{F})$ are pointing the confluence of the vagina and the urethra ("u"). Axial T2-weighted MRI of the pelvis showing prostate tissue (dashed arrows in $\mathbf{D}$ ) in this patient. The pattern of the adrenal glands and presence of mullerian derivatives allowed institution of therapy while laboratory tests were done to confirm congenital adrenal hyperplasia in this XX neonate. MRI and genitography were requested for planning feminizing surgery.

Although the clinical features of $\mathrm{CAH}$ are usually present, testicular adrenal rest tumor (TART) may be the only clinical finding at presentation (11). Based on microscopic studies, TARTs are reported to be present in all males with CAH (12). On US, it has been documented with a prevalence of up to $94 \%$ (13). The most common sonographic features are bilateral spikelike appearance intratesticular hypoechoic masses with no sound attenuation, surrounding the mediastinal testis (11). On color Doppler they are hypo or avascular (14) and there is no deviation or changes in caliber of the vessels that course the lesions $(11,14)$. However, TART may also appear as heterogeneous or hyperechoic nodules $(11,14,15)$, and even as an epididymal nodule (11). TART echogenicity is related to the size of the lesions, being hypoechoic in lesions smaller than $2 \mathrm{~cm}$ and heterogeneous or hyperechoic in lesions larger than $2 \mathrm{~cm}$ (14). These hyperechoic areas may represent fibrosis or calcifications (14). In addition, larger lesions may not be confined to the mediastinal testis and smaller lesions are more often seen unilaterally (14). On follow-up, TART can vary in size (15), but there is no correlation between hormonal control or hormonal markers and TART (15-17). TARTs are thought to be responsible for testicular parenchymal damage that contributes to reduced fertility $(17,18)$. It can be found even in young children with a prevalence of $21 \%$ (19) and it is suggested that gonadal dysfunction is already present before puberty (19). Therefore, early detection of testicular lesions is advised (20) to improve treatment and prevent longstanding gonadal impairment function. Thus, some authors advocate that not only adolescents should undergo US (21) (Figure 2).

High prevalence of impaired fertility is not restricted to men as it was reported also in women with $\mathrm{CAH}$ $(13,17)$. The prevalence of polycystic ovaries is increased in women with classical and nonclassical CAH (22). Bilateral enlarged ovaries (23), bilateral ovarian cysts, and ovarian adrenal rest tumors (OART) (24) may occur and can also be depicted by US. OART may present as hypoechoic nodules on US $(24,25)$, similar to TART.

The most common cause of disorders of sex differentiation in the perinatal period is $\mathrm{CAH}$. A clue to the prenatal diagnosis of $\mathrm{CAH}$ is usually the presence of ambiguous genitalia that may be present by the second trimester. The most often presentation is of an enlarged clitoris, but more complex abnormalities can be seen (26). 
In postnatal period, to assess internal anatomy of the pelvis, US is the first choice (Figure 1C). It is easily performed and must include images of the pelvis, scrotum, inguinal, perineal, renal, and adrenal regions (27). The main purpose of the pelvic sonography is to depict accurately the size and morphology of the Mullerian structures, the uterus, the vagina, and the gonads (3). In addition to the adrenal glands findings described above, the presence of a uterus in a patient with ambiguous genitalia indicates that the diagnosis is mostly likely $\mathrm{CAH}$ (9). Ultrasound evaluation of the pelvic structures is not only performed for diagnosis but also as part of the preoperative approach for surgery, often in conjunction with other exams, such as genitography and MRI (3). US provides adequate information about the vagina and urogenital sinus for preoperative decision-making (28).

Many other abnormalities in patients with $\mathrm{CAH}$ can also be demonstrated by US: cardiac dysfunction that reverses with therapy (29), vascular dysfunction and increased carotid intima media thickness (30), skeletal and midface malformations associated with P450 oxidoreductase deficiency in prenatal diagnosed fetuses (31), hydrops of placental stem villi in a $46, \mathrm{XX}$ fetus (32), association with increased nuchal translucency detected in the prenatal period (33), bilateral ovarian steroid cell tumor in a girl with CAH 11 beta-hydroxylase deficiency (34), and adrenal rest tissue extending from the lower pole of the kidney (35).

\section{Computed tomography}

Adrenocortical tumors in patients with $\mathrm{CAH}$ are not rare. A prevalence of up to $83 \%$ of adrenocortical masses in homozygote patients is reported (36). Despite this high frequency, adrenocortical tumors in this setting are most likely to be benign, as malignant lesions are rare (36). In many reports CT scans showed nodules (36-38) that may regress with adequate therapy (37), adenomas (23), myelolipomas (39), and the typical pattern of diffuse enlargement (38) with a heterogeneous enhancement (Figure 3).

Positron emission tomography with CT scan (PET$\mathrm{CT}$ ) was used in 3 case reports. In one, PET-CT was used to evaluate an adrenal mass in an untreated patient and showed a mass proved to be an adrenocortical tumor of uncertain prognosis (40). In the other two, PET-CT depicted OARTs $(25,41)$, interestingly, in one of these reports both MRI and CT could not shown this finding. On the other hand, adrenal rest tumors have already been described on conventional CT as a soft tissue masse in the ovary, OART (42), and in the perirenal region (43).

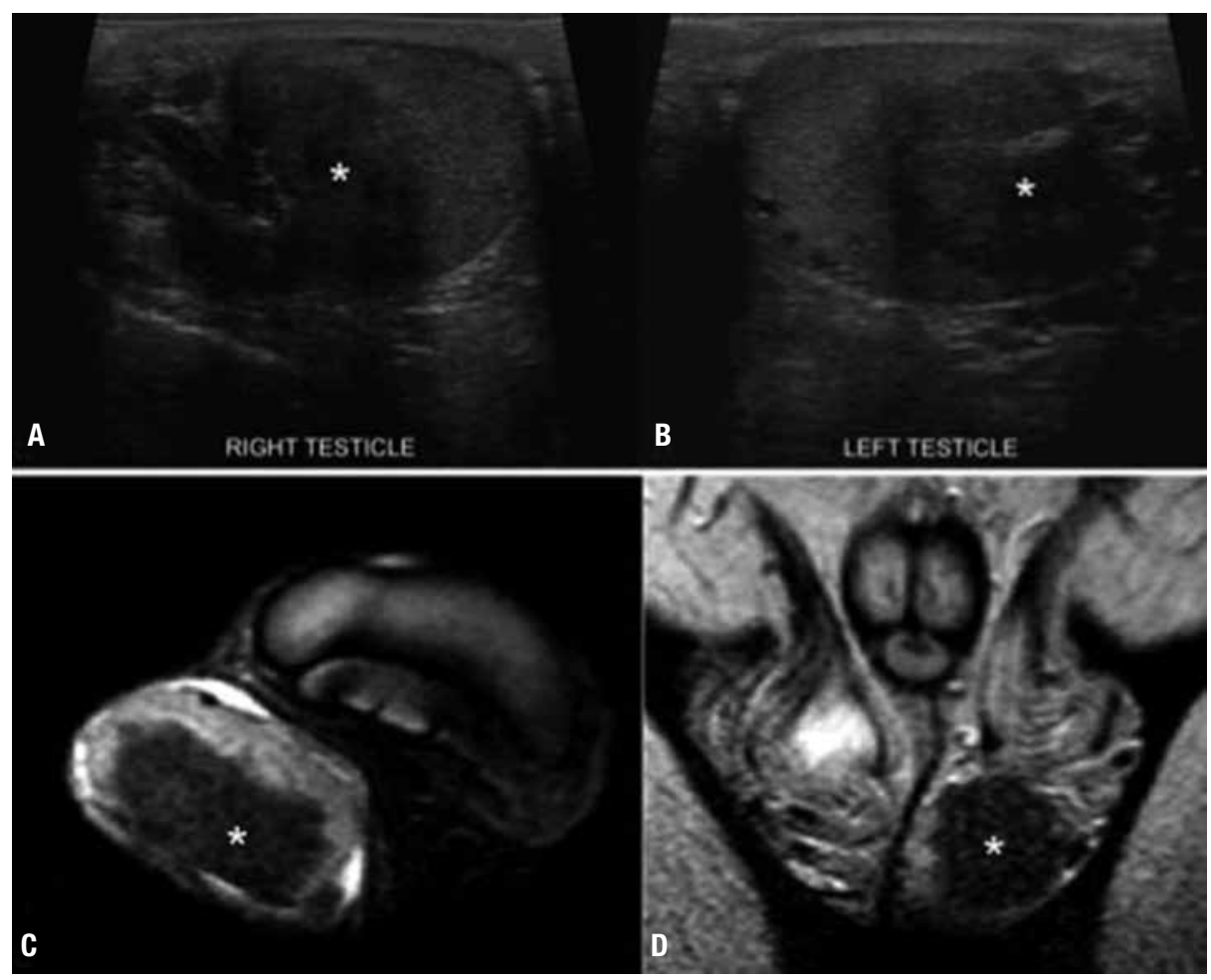

Figure 2. Testicular adrenal rest tumor (TART) in a 14 year-old male, with simple virilizing congenital adrenal hyperplasia. On ultrasonography (A-B), there is a round heterogeneous, predominantly hypoechoic nodule $\left(^{*}\right)$ within both testicles, in the region of the mediastinal testis. On magnetic resonance imaging (C, axial; D, coronal) the TARTs are hypointense on T2-weighted images. 

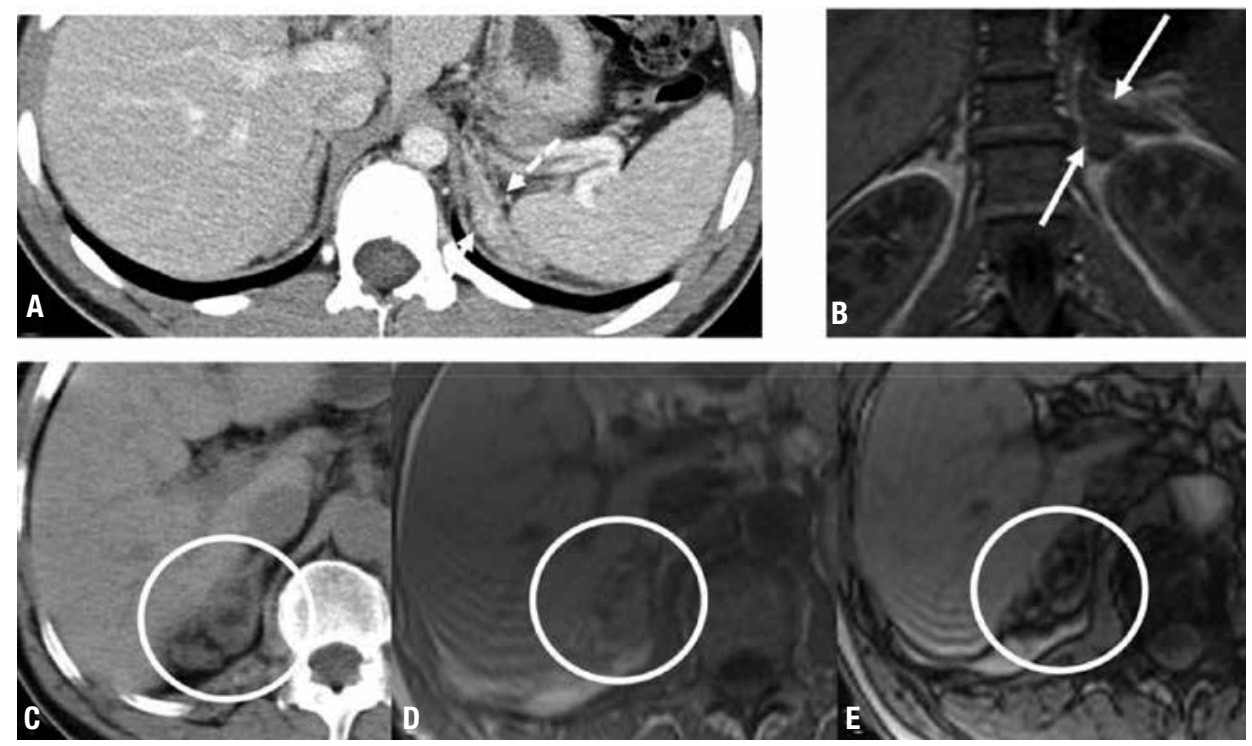

Figure 3. Adrenal glands in three different patients with congenital adrenal hyperplasia (CAH). Enlarged adrenal glands (arrows) can be seen on computed tomography $(\mathbf{A})$ and magnetic resonance imaging (B), in different patients. On "A", the left adrenal gland had nodular margins (dashed arrow). On "B" the left adrenal gland (dashed arrow) is larger than the right adrenal gland, which was within normal limits. Another adult patient with abdominal pain in which ultrasonography (not shown) depicted an adrenal mass. Computed tomography (C) and magnetic resonance imaging (D-E) showed a right adrenal myelolipoma (circles). CAH was confirmed posteriorly. Axial contrast-enhanced computed tomography (A); coronal T1-weighted magnetic resonance imaging (B); axial computed tomography (C) and T1-in-phase (D) and out-of-phase (E) magnetic resonance imaging.

\section{Magnetic resonance imaging}

Studies based on MRI are in accordance with others performed with CT (36) demonstrating a high prevalence of adrenal nodules $(73 \%)$ in adults with $\mathrm{CAH}$ (16). Moreover, adrenal MRI imaging in CAH patients showed findings such as normal or diffuse enlarged adrenal glands (44), adrenal nodules $(16,37,45)$, and myelolipomas $(46,47)$, which is consistent with US and CT findings (Figure 3 ). The size of the adrenal glands and presence of nodules may relate to hormonal control status; a significant correlation between adrenal and nodule sizes and hormonal parameters has been described (16). Moreover, these morphological adrenal features are more prevalent in patients with a poor hormonal control status (48), even as the prevalence of adrenal masses increases with adrenal volume (16), which may regress with adequate treatment (49).

Excellent soft-tissue contrast, spatial resolution, and capability of multiplanar imaging make MRI more sensitive than other imaging modalities to evaluate the pelvis. MRI is indicated when US fails to adequately demonstrate the morphology, size, and relationship between Mullerian duct derivatives in virilized female infants $(3,27)$ (Figure 1$)$. It is the primary imaging modality when evaluation of pelvic organs and morphology in older children, adolescents, and adults are needed. In addition, although rare, prostatic tissue has been shown in females with $\mathrm{CAH}$ with a prevalence of up to $15 \%(50)$.

The prevalence of ectopic adrenal rest tumors in the testicles showed by MRI is high, ranging from around 29\% (32) to 94\% (14). Despite this high incidence, presence of TART did not show any correlation with short hormonal parameters in adults (16). On MRI, TARTs are typically isointense relatively to parenchyma on Tl-weighted images, hypointense on T2-weighted images (14,51), and present well-defined margins (14). After intravenous injection of gadolinium they have a significant enhancement (51). Although MRI has the same sensitivity as US in detecting TART (5l), when testis sparing surgery is considered MRI is recommended due to its better depiction of the tumor margins (14). Adrenal rest tissue was also documented in the retroperitoneum encasing the aorta with regression of the size after glucocorticoid treatment (52).

Concerning brain changes in patients with $\mathrm{CAH}$, MRI showed white matter abnormalities (53), smaller amygdalas (54), and temporal lobe atrophy in young population (55). White matter abnormalities may also be secondary to electrolytic complications of the disease (56). Pituitary abnormalities (57) and hypothalamic hamartoma (58) were described in $\mathrm{CAH}$ patients 
in anecdotal case reports. Functional MRI demonstrated different patterns of activation in emotional memory comparing $\mathrm{CAH}$ patients with controls (59), and a virilized amygdala function in females affected (60).

\section{CONCLUSIONS}

Although the diagnosis of $\mathrm{CAH}$ is based on hormonal dosages and genetic analysis, imaging still has an important role in the management of these patients regarding a proper clinical setting. In addition to radiographs evaluating bone age included as a tool in the clinical follow-up, genitography, US, MRI, CT, and other imaging modalities add important information for diagnosis, follow-up, and surgical planning (Table 1).

The detection of TART is essential to be done as early as possible, as the patients can be monitored and treated more intensively, in order to prevent fertility impairment and testicles damage (20). US figures as the modality of choice for this purpose $(20,51)$. Therefore, it should be used routinely and not only from adolescence. While laboratorial results are pending, US may show a specific coiled pattern and/or enlargement of the adrenal glands (6), enabling early treatment of neonates with suspicious of CAH. Furthermore, US is the first modality to evaluate neonates and young infants with ambiguous genitalia (27), a feature frequently present in virilized females. As a tool to help early detection of risk for cardiovascular diseases, US may be used to evaluate carotid vessels (30).

MRI is a problem solving for detailed depiction of pelvic structures when US in not sufficient, mainly in cases of ambiguous genitalia $(3,27)$. It is recommended to evaluate TART before testes sparing surgery (14). Also, MRI can evaluate in detail adrenal nodules. Due to its lack of radiation and better soft tissue contrast, MRI may be considered as the method of choice to follow-up patients, as adrenal changes on MRI correlate to hormonal parameters (16). CT is mainly used to evaluate the adrenal glands but with the drawback of

Table 1. Summary of the imaging approach in evaluation of variable conditions related to congenital adrenal hyperplasia

\begin{tabular}{|c|c|c|c|c|c|c|c|}
\hline $\begin{array}{l}\text { Imaging } \\
\text { modality }\end{array}$ & Adrenal glands & $\begin{array}{l}\text { Genitalia } \\
\text { ambigua }\end{array}$ & TART & OART & Others & Advantages & Disadvantages \\
\hline US & $\begin{array}{l}\text { Modality of choice } \\
\text { in children }\end{array}$ & Initial study & $\begin{array}{l}\text { Modality of choice } \\
\text { for diagnosis and } \\
\text { follow-up }\end{array}$ & Initial study & Carotid vessels & $\begin{array}{l}\text { - Relatively } \\
\text { low-cost } \\
\text { - Lack of ionizing } \\
\text { radiation } \\
\text { exposure } \\
\text { - Availability }\end{array}$ & $\begin{array}{l}\text { - Heavily } \\
\text { operator- } \\
\text { dependent } \\
\text { - Limited } \\
\text { depending on } \\
\text { the body } \\
\text { habitus }\end{array}$ \\
\hline MRI & $\begin{array}{l}\text { Diagnosis and } \\
\text { follow-up of } \\
\text { nodules } \\
\text { - Volumetry }\end{array}$ & $\begin{array}{l}\text { - Detailed pelvic } \\
\text { anatomy } \\
\text { - Problem } \\
\text { resolving when } \\
\text { US fails }\end{array}$ & $\begin{array}{l}\text { Before testis- } \\
\text { sparing surgery }\end{array}$ & $\begin{array}{l}\text { May help in the } \\
\text { diagnosis }\end{array}$ & $\begin{array}{l}\text { Modality of choice } \\
\text { for the central } \\
\text { nervous system }\end{array}$ & $\begin{array}{l}\text { - High tissue } \\
\text { contrast } \\
\text { - Detailed } \\
\text { anatomy } \\
\text { - Lack of ionizing } \\
\text { radiation } \\
\text { exposure }\end{array}$ & $\begin{array}{l}\text { - } \text { Need for } \\
\text { sedation in } \\
\text { some cases } \\
\text { - Costs }\end{array}$ \\
\hline CT & $\begin{array}{l}\text { Initial study in } \\
\text { evaluation of } \\
\text { nodules* }^{*}\end{array}$ & - & - & - & - & $\begin{array}{l}\text { - } \text { Rapid } \\
\text { acquisition } \\
\text { - High spatial } \\
\text { resolution }\end{array}$ & $\begin{array}{l}\text { - Ionization } \\
\text { radiation } \\
\text { exposure } \\
\text { - Low soft-tissue } \\
\text { contrast } \\
\text { compared to } \\
\text { MRI }\end{array}$ \\
\hline GX & - & $\begin{array}{l}\text { Preoperative in } \\
\text { feminizing surgery }\end{array}$ & - & - & - & $\begin{array}{l}\text { - Anatomic } \\
\text { detailed image } \\
\text { of the urogenital } \\
\text { sinus and } \\
\text { urethra } \\
\text { - Evaluation of } \\
\text { vesicoureteral } \\
\text { reflux }\end{array}$ & $\begin{array}{l}\text { - lonizing } \\
\text { radiation } \\
\text { exposure } \\
\text { - May not show } \\
\text { the cervical } \\
\text { impression of } \\
\text { the uterus }\end{array}$ \\
\hline
\end{tabular}

US: ultrasonography; MRI: magnetic resonance imaging; CT: computed tomography; GX: genitography; TART: testicular adrenal rest tumor; OART: ovarian adrenal rest tumor.

* If MRI is not available, which has higher sensitivity and specificity than CT and lack of ionizing radiation exposure. 
ionizing radiation. To assess pelvic anatomy, genitography is used for planning feminizing surgery (3).

For radiologists and sonographers, the detection of enlarged adrenal glands, adrenal gland nodules, and coiled adrenal glands in any imaging study should prompt raise the possibility of $\mathrm{CAH}$. Also, they must keep in mind the possibility of $\mathrm{CAH}$ in cases of ambiguous genitalia, testis lesions, ovarian solid nodules, abnormal retroperitoneum solid tissues, and even white matter abnormalities seen in brain MRI.

Disclosure: no potential conflict of interest relevant to this article was reported.

\section{REFERENCES}

1. Merke DP, Bornstein SR. Congenital adrenal hyperplasia. Lancet. 2005;365(9477):2125-36.

2. Speiser PW, Azziz R, Baskin LS, Ghizzoni L, Hensle TW, Merke DP, et al. Congenital adrenal hyperplasia due to steroid 21-hydroxyIase deficiency: an Endocrine Society clinical practice guideline. J Clin Endocrinol Metab. 2010;95(9):4133-60.

3. Chavhan GB, Parra DA, Oudjhane K, Miller SF, Babyn PS, Pippi Salle FL. Imaging of ambiguous genitalia: classification and diagnostic approach. Radiographics. 2008;28(7):1891-904.

4. Nabhan ZM, Eugster EA. Upper-tract genitourinary malformations in girls with congenital adrenal hyperplasia. Pediatrics. 2007;120(2):e304-7.

5. Vanderbrink BA, Rink RC, Cain MP, Kaefer M, Meldrum KK, Misseri $R$, et al. Does preoperative genitography in congenital adrenal hyperplasia cases affect surgical approach to feminizing genitoplasty? J Urol. 2010;184(4 Suppl):1793-8.

6. Sivit CJ, Hung W, Taylor GA, Catena LM, Brown-Jones C, Kushner DC. Sonography in neonatal congenital adrenal hyperplasia. AJR Am J Roentgenol. 1991;156(1):141-3.

7. Hauffa BP, Menzel D, Stolecke H. Age-related changes in adrenal size during the first year of life in normal newborns, infants and patients with congenital adrenal hyperplasia due to 21-hydroxylase deficiency: comparison of ultrasound and hormonal parameters. Eur J Pediatr. 1988;148(1):43-9.

8. Avni EF, Rypens F, Smet MH, Galetty E. Sonographic demonstration of congenital adrenal hyperplasia in the neonate: the cerebriform pattern. Pediatr Radiol. 1993;23(2):88-90.

9. Hernanz-Schulman M, Brock JW, 3rd, Russell W. Sonographic findings in infants with congenital adrenal hyperplasia. Pediatr Radiol. 2002;32(2):130-7.

10. Saada J, Grebille AG, Aubry MC, Rafii A, DumezY, Benachi A. Sonography in prenatal diagnosis of congenital adrenal hyperplasia. Prenat Diagn. 2004;24(8):627-30.

11. Avila NA, Premkumar A, Shawker TH, Jones JV, Laue L, Cutler GB, Jr. Testicular adrenal rest tissue in congenital adrenal hyperplasia: findings at Gray-scale and color Doppler US. Radiology. 1996;198(1):99-104.

12. Shanklin DR, Richardson AP Jr, Rothstein G. Testicular hilar nodules in adrenogenital syndrome. The nature of the nodules. Am J Dis Child. 1963;106:243-50.

13. Stikkelbroeck NM, Otten BJ, Pasic A, Jager GJ, Sweep CG, Noordam K, et al. High prevalence of testicular adrenal rest tumors, impaired spermatogenesis, and Leydig cell failure in adolescent and adult males with congenital adrenal hyperplasia. J Clin Endocrinol Metab. 2001;86(12):5721-8.

14. Stikkelbroeck NM, Suliman HM, Otten BJ, Hermus AR, Blickman JG, Jager GJ. Testicular adrenal rest tumours in postpubertal males with congenital adrenal hyperplasia: sonographic and MR features. Eur Radiol. 2003;13(7):1597-603.

15. Avila NA, Shawker TS, Jones JV, Cutler GB Jr, Merke DP. Testicular adrenal rest tissue in congenital adrenal hyperplasia: serial sonographic and clinical findings. AJR Am J Roentgenol. 1999;172(5):1235-8.

16. Reisch N, Scherr M, Flade L, Bidlingmaier M, Schwarz HP, Müller-Lisse $U$, et al. Total adrenal volume but not testicular adrenal rest tumor volume is associated with hormonal control in patients with 21-hydroxylase deficiency. J Clin Endocrinol Metab. 2010;95(5):2065-72.

17. Reisch N, Flade L, Scherr M, Rottenkolber M, Pedrosa Gil F, Bidlingmaier $M$, et al. High prevalence of reduced fecundity in men with congenital adrenal hyperplasia. J Clin Endocrinol Metab. 2009;94(5):1665-70.

18. Claahsen-van der Grinten HL, Otten BJ, Hermus AR, Sweep FC, Hulsbergen-van de Kaa CA. Testicular adrenal rest tumors in patients with congenital adrenal hyperplasia can cause severe testicular damage. Fertil Steril. 2008;89(3):597-601.

19. Martinez-Aguayo A, Rocha A, Rojas N, et al. Testicular adrenal rest tumors and Leydig and Sertoli cell function in boys with classical congenital adrenal hyperplasia. J Clin Endocrinol Metab. 2007;92(12):4583-9.

20. Claahsen-van der Grinten HL, Otten BJ, Stikkelbroeck MM, Sweep FC, Hermus AR. Testicular adrenal rest tumours in congenital adrenal hyperplasia. Best Pract Res Clin Endocrinol Metab. 2009;23(2):209-20.

21. Dieckmann K, Lecomte P, Despert F, Maurage C, Sirinelli D, Rolland JC. [Congenital adrenal hyperplasia and testicular hypertrophy]. Arch Pediatr. 1995;2(12):1167-72.

22. New MI. Nonclassical congenital adrenal hyperplasia and the polycystic ovarian syndrome. Ann NY Acad Sci. 1993;687:193-205.

23. Forsbach G, Guitron-Cantu A, Vazquez-Lara J, Mota-Morales M, Diaz-Mendoza ML. Virilizing adrenal adenoma and primary amenorrhea in a girl with adrenal hyperplasia. Arch Gynecol Obstet. 2000;263(3):134-6.

24. Russo G, Paesano P, Taccagni G, Del Maschio A, Chiumello G. Ovarian adrenal-like tissue in congenital adrenal hyperplasia. $\mathrm{N}$ Engl J Med. 1998;339(12):853-4.

25. Tiosano D, Vlodavsky E, Filmar S, Weiner Z, Goldsher D, Bar-Shalom R. Ovarian adrenal rest tumor in a congenital adrenal hyperplasia patient with adrenocorticotropin hypersecretion following adrenalectomy. Horm Res Paediatr. 2010;74(3):223-8.

26. Sivan E, Koch S, Reece EA. Sonographic prenatal diagnosis of ambiguous genitalia. Fetal Diagn Ther. 1995;10(5):311-4.

27. Garel L. Abnormal sex differentiation: who, how and when to image. Pediatr Radiol. 2008;38 Suppl 3:S508-11.

28. Chertin B, Hadas-Halpern I, Fridmans A, Kniznik M, Abu-Arafeh W, Zilberman $M$, et al. Transabdominal pelvic sonography in the preoperative evaluation of patients with congenital adrenal hyperplasia. J Clin Ultrasound. 2000;28(3):122-4.

29. Minette MS, Hoyer AW, Pham PP, DeBoer MD, Reller MD, Boston BA. Cardiac function in congenital adrenal hyperplasia: a pattern of reversible cardiomyopathy. J Pediatr. 2013;162(6):1193-8, 8 e1.

30. Wasniewska M, Balsamo A, Valenzise M, Manganaro A, Faggioli G, Bombaci S, et al. Increased large artery intima media thickness in adolescents with either classical or non-classical congenital adrenal hyperplasia. J Endocrinol Invest. 2013;36(1):12-5.

31. Reisch N, Idkowiak J, Hughes BA, Ivison HE, Abdul-Rahman OA, Hendon LG, et al. Prenatal diagnosis of congenital adrenal hyper- 
plasia caused by P450 oxidoreductase deficiency. J Clin Endocrinol Metab. 2013;98(3):E528-36.

32. Furuhashi $\mathrm{M}, \mathrm{Oda} \mathrm{H}$, NakashimaT. Hydrops of placental stem villi complicated with fetal congenital adrenal hyperplasia. Arch Gynecol Obstet. 2000;264(2):101-4.

33. Fincham J, Pandya PP, Yuksel B, Loong YM, Shah J. Increased first-trimester nuchal translucency as a prenatal manifestation of salt-wasting congenital adrenal hyperplasia. Ultrasound Obstet Gynecol. 2002;20(4):392-4.

34. Baş F, Saka N, Darendeliler F, Tuzlali S, Ilhan R, Bundak R, et al. Bilateral ovarian steroid cell tumor in congenital adrenal hyperplasia due to classic 11 beta-hydroxylase deficiency. J Pediatr Endocrinol Metab. 2000;13(6):663-7.

35. Souverijns G, Peene P, Keuleers H, Vanbockrijck M. Ectopic localisation of adrenal cortex. Eur Radiol. 2000;10(7):1165-8.

36. Jaresch S, Kornely E, Kley HK, Schlaghecke R. Adrenal incidentaloma and patients with homozygous or heterozygous congenital adrenal hyperplasia. J Clin Endocrinol Metab. 1992;74(3):685-9.

37. Giacaglia LR, Mendonca BB, Madureira G, Melo KF, Suslik CA, Arnhold IJ, et al. Adrenal nodules in patients with congenital adrenal hyperplasia due to 21-hydroxylase deficiency: regression after adequate hormonal control. J Pediatr Endocrinol Metab. 2001;14(4):415-9.

38. Harinarayana CV, Renu G, Ammini AC, Khurana ML, Ved P, Karmarkar MG, et al. Computed tomography in untreated congenital adrenal hyperplasia. Pediatr Radiol. 1991;21(2):103-5.

39. Mermejo LM, Elias Junior J, Saggioro FP, Tucci Junior S, Castro Md, Moreira AC, et al. Giant adrenal myelolipoma associated with 21-hydroxylase deficiency: unusual association mimicking an androgen-secreting adrenocortical carcinoma. Arq Bras Endocrinol Metabol. 2010;54(4):419-24.

40. Chevalier N, Carrier P, Piche M, Chevallier A, Wagner K, Tardy V, et al. Adrenocortical incidentaloma with uncertain prognosis associated with an inadequately treated congenital adrenal hyperplasia. Ann Endocrinol (Paris). 2010;71(1):56-9.

41. Crocker MK, Barak S, Millo CM, Beall SA, Niyyati M, Chang R, et al. Use of PET/CT with cosyntropin stimulation to identify and localize adrenal rest tissue following adrenalectomy in a woman with congenital adrenal hyperplasia. J Clin Endocrinol Metab. 2012;97(11):E2084-9.

42. Al-Ahmadie HA, Stanek J, Liu J, Mangu PN, NiemannT, Young RH. Ovarian 'tumor' of the adrenogenital syndrome: the first reported case. Am J Surg Pathol. 2001;25(11):1443-50.

43. Claahsen-van der Grinten HL, Duthoi K, Otten BJ, d'Ancona FC, Hulsbergen-vd Kaa CA, Hermus AR. An adrenal rest tumour in the perirenal region in a patient with congenital adrenal hyperplasia due to congenital 3beta-hydroxysteroid dehydrogenase deficiency. Eur J Endocrinol. 2008;159(4):489-91.

44. Azziz R, Kenney PJ. Magnetic resonance imaging of the adrenal gland in women with late-onset adrenal hyperplasia. Fertil Steril. 1991;56(1):142-4.

45. Chervin RA, Danilowicz K, Pitoia F, Gomez RM, Bruno OD. [A study of 34 cases of adrenal incidentaloma]. Medicina (B Aires). 2007;67(4):341-50.
46. Nagai T, Imamura M, Honma M, Murakami M, Mori M. 17alphahydroxylase deficiency accompanied by adrenal myelolipoma. Intern Med. 2001;40(9):920-3.

47. Umpierrez MB, Fackler S, Umpierrez GE, Rubin J. Adrenal myelolipoma associated with endocrine dysfunction: review of the literature. Am J Med Sci. 1997;314(5):338-41.

48. Bachega TAM J, Madureira G, Suslik CA, Gomes GC, Secaf E, Bloise W, et al. Adrenal image studies in patients with congenital adrenal hyperplasia due to 21-hydroxylase deficiency. 7th Annual Meeting of the Sociedad Latinoamericana de Endocrinologia Pediatrica. Itapanema, Brasil. 1993. p. 678.

49. Mokshagundam S, Surks MI. Congenital adrenal hyperplasia diagnosed in a man during workup for bilateral adrenal masses. Arch Intern Med. 1993;153(11):1389-91.

50. Paulino Mda C, Steinmetz L, Menezes Filho HC, Kuperman $\mathrm{H}$, Della MannaT, Vieira JG, et al. [Search of prostatic tissue in $46, X X$ congenital adrenal hyperplasia]. Arq Bras Endocrinol Metabol. 2009;53(6):716-20.

51. Avila NA, Premkumar A, Merke DP.Testicular adrenal rest tissue in congenital adrenal hyperplasia: comparison of MR imaging and sonographic findings. AJR Am J Roentgenol. 1999;172(4):1003-6.

52. Storr HL, BarwickTD, Snodgrass GA, Booy R, MorelY, Reznek RH, et al. Hyperplasia of adrenal rest tissue causing a retroperitoneal mass in a child with 11 beta-hydroxylase deficiency. Horm Res. 2003;60(2):99-102.

53. Sinforiani E, Livieri C, Mauri M, Bisio P, Sibilla L, Chiesa L, et al. Cognitive and neuroradiological findings in congenital adrenal hyperplasia. Psychoneuroendocrinology. 1994;19(1):55-64.

54. Rose AB, Merke DP, Clasen LS, Rosenthal MA, Wallace GL, Vaituzis $A C$, et al. Effects of hormones and sex chromosomes on stressinfluenced regions of the developing pediatric brain. Ann N Y Acad Sci. 2004;1032:231-3.

55. Nass R, Heier L, Moshang T, Oberfield S, George A, New MI, et al. Magnetic resonance imaging in the congenital adrenal hyperplasia population: increased frequency of white-matter abnormalities and temporal lobe atrophy. J Child Neurol. 1997;12(3):181-6.

56. Lee S, Sanefuji M, Watanabe K, Uematsu A, Torisu H, Baba H, et al. Clinical and MRI characteristics of acute encephalopathy in congenital adrenal hyperplasia. J Neurol Sci. 2011;306(1-2):91-3.

57. Speiser PW, Heier L, Serrat J, New MI, Nass R. Failure of steroid replacement to consistently normalize pituitary function in congenital adrenal hyperplasia: hormonal and MRI data. Horm Res. 1995;44(6):241-6.

58. Pasquino AM, Pucarelli I, Cambiaso P, Cappa M. Precocious puberty with hypothalamic hamartoma and non classical form of congenital adrenal hyperplasia. Report of two cases. Minerva Pediatr. 2009;61(5):561-4.

59. Mazzone L, Mueller SC, Maheu F, VanRyzin C, Merke DP, Ernst M. Emotional memory in early steroid abnormalities: an FMRI study of adolescents with congenital adrenal hyperplasia. Dev Neuropsychol. 2011;36(4):473-92.

60. Ernst M, Maheu FS, Schroth E, Hardin J, Golan LG, Cameron J, et al. Amygdala function in adolescents with congenital adrenal hyperplasia: a model for the study of early steroid abnormalities. Neuropsychologia. 2007:45(9):2104-13. 